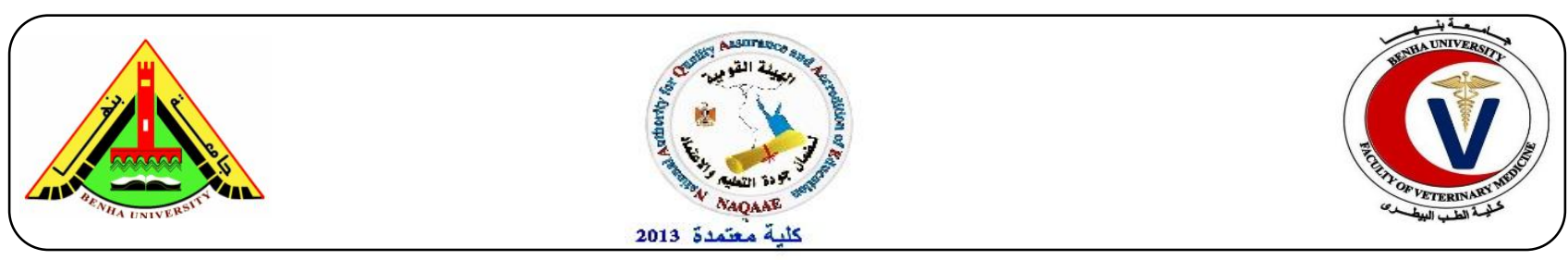

\title{
Chemical Preservatives in Some Meat Products
}

\author{
Hassan,M.A ${ }^{1}$, Amin, R.A. ${ }^{1}$, El-Taher, O.M ${ }^{2}$ and Meslam,E.M ${ }^{2}$. \\ Food hygiene and Control Dep., Fac. Vet, Med.,BenhaUniv¹. \\ Animal Health Research Institute, Dokki².
}

\section{A B S T R A C T}

A grand total of 120 random samples of meat products represented by beef burger, beef sausage, beef minced meat and beef kofta (30 of each) were collected from different supermarkets located in Cairo and Giza. The average of nitrite, phosphate, ascorbic acid and monosodium glutamate levels (ppm) were $24.14 \pm 1.96$, zero, $111.33 \pm 9.49$ and $983.12 \pm 45.71$ in the examined minced meat, respectively,38.53 $\pm 2.17,0.13 \pm 0.01,190.10 \pm 14.26$ and $1849.27 \pm 92.69$ in the examined kofta, respectively,36.89 $\pm 2.02,0.21 \pm 0.01,227.60 \pm 16.81$ and $1139.90 \pm 73.14$ in the examined beef burger, respectively and $43.59 \pm 2.33,0.16 \pm 0.01,265.67 \pm 21.04$ and $1958.83 \pm 101.35 \mathrm{in}$ the examined sausage, respectively.

Key words: Meat products, Nutritional criteria, Chemical preservatives, Nitrite, Phosphate, Ascorbic acid, MSG.

(http://www.bvmj.bu.edu.eg)

(BVMJ-35(1): 58-65, 2018)

\section{INTRODUCTION}

The modern technology in different fields gives chance for the meat processors to produce new products in different shapes, easily handled, stored and used. The need for meat products have many tasks includes, new flavor, preservation and low fat content and of low calories so, the quality of raw material (meat) as well as additives and final products are very important for public health. Therefore, the use of low quality ingredients in processing yields low quality meat products (Pearson and Gillette, 1996).

Food additives are used to accomplish certain functions such as coloring, antimicrobial, antioxidative, preservation, improved nutrition, increased emulsification, and altered flavor (Davidson, 2001).Acceptance of food additives has been hindered by problems involving assessment of the net benefits of their use. A serious public health problem has been arisen in many countries where the use of food additives has become more widespread (Denner, 1990).

Nitrite and nitrite addition is necessary to prevent spoilage and growth of pathogenic microorganisms (Pivinick et al., 1970) as its absence increase the risk of poisoning especially botulism( Jouve et al., 1980).

Phosphate are used in meat products for several reasons such as changing and/or stabilizing the $\mathrm{pH}$ value, increasing water holding capacity in order to lead higher yields, decreasing losses of weight in cooking, improving texture and sensory properties (tenderness, juiciness, color and flavor), extending shelf life, etc. In addition, phosphate in meat products are also sources 
of supply of phosphorus for consumers through diet, which is an essential mineral for the life of humans (Long et al., 2011).

Monosodium glutamate (MSG) is one of the most abundant naturally occurring amino acids which frequently added as a flavor enhancer. It produced a unique taste that cannot be provided by other taste (saltiness, sourness and bitterness), referred to as a fifth taste (umami). Glutamate serves some functions in the body as well, serving as an energy source for certain tissues and as a substrate for glutathione synthesis (Jinap and Hajeb, 2010).

Ground meat tends to become brown and rancid more rapidly than whole muscle retail cuts (Ho et al. 1996). Both myoglobin and lipid oxidation processes are closely related (Faustman and Cassens 1989), so it may be argued that the presence of an antioxidant as ascorbic acid would inhibit both discoloration and off-odor formation.

\section{RESULTS}

Regarding to data obtained in table (1), it is indicated that the nitrite levels (ppm) in the examined meat product samples was varied from 15.98 to 40.98 with an average of $24.14 \pm 1.96$ for minced meat, 16.24 to 81.34 with an average $38.53 \pm 2.17$ for kofta, 20.56 to 68.65 with an average of $36.89 \pm 2.02$ for beef burger and 7.02 to 83.01 with an average of $43.59 \pm 2.33$ for sausage. The incidence of nitrite in the examined meat products, the detectable positive samples were $46.7 \%$, $100 \%, 86.7 \%$ and $100 \%$ of the examined minced meat, kofta, beef burger and sausage, respectively.

Also, table (6) showed that14 samples $(46.7 \%)$ of minced meat, 18 samples $(60 \%)$ of kofta, 25 samples $(83.33 \%)$ of beef burger and 13 samples $(43.33 \%)$ of sausage contain nitrite and not prescribed on the label of these samples and this disagree with the recommendation of EOS (2010).
Therefore the present study was planned to investigate the chemical preservatives of some meat products as beef burger, kofta, minced meat and sausage.

\section{MATERIALS AND METHODS}

2.1. Collection of Samples:

A grand total of 120 random samples of meat products represented by beef burger, beef sausage, beef minced meat and beef kofta (30 of each) were collected from different supermarkets located Cairo and Giza and transferred to the laboratory in an insulated ice box.

2.2. Determination of chemical preservatives:

2.3.1. Determination of nitrites (AOAC, 2016).

2.3.2. Determination of phosphate content( EOS 4485, 2008).

2.3.3. Determination of ascorbic acid (AOAC, r.17).

2.3.4. Determination of Monosodium glutamate by HPLC (Lateef et al., 2012).

The results reported in table (2) revealed that the phosphate $\%$ in the examined meat product samples was varied from 0.05 to 0.30 with an average $0.13 \pm$ 0.01 for kofta, 0.11 to 0.28 with an average of $0.21 \pm 0.01$ for beef burger and 0.05 to 0.35 with an average of $0.16 \pm 0.01$ for sausage. Phosphate failed to detect in all examined minced meat samples, while detected in $100 \%, 40 \%$ and $100 \%$ of examined beef kofta, beef burger and sausage samples, respectively. Also, the results in table (2) indicated that the phosphate detected in all examined minced meat, kofta, beef burger and sausage were prescribed on label.

Moreover table (3) revealed that the ascorbic acid (ppm) in the examined meat product samples was varied from 106.6 to 115.7 with an average $111.33 \pm 9.49$ for minced meat, 180.6 to 203.0 with an average of $190.10 \pm 14.26$ for kofta, 213.7 to 250.4 with an average of $227.60 \pm 16.81$ for beef burger and 261.0 to 270.0 with an average of 
$265.67 \pm 21.04$ for sausage. The detectable positive samples were 6 samples (20\%), 6 samples (20\%), 6 samples $(20 \%)$ and 26 samples $(86.7 \%)$ of the examined minced meat, kofta, beef burger and sausage, respectively. Also, the results in table (3) indicated that the ascorbic acid detected in all examined minced meat, kofta, beef burger and sausage were prescribed on label.

Concerning the results obtained in table (4) revealed that the monosodium glutamate levels (ppm) in the examined meat product samples was varied from 588.1to 1284.7with an average $983.12 \pm$ 45.71for minced meat, 1119.8 to 3026.2 with an average of $1849.27 \pm 92.69$ for kofta, 752.3 to 1618.5 with an average of $1139.90 \pm 73.14$ for beef burger and 935.2 to 2675.1 with an average of $1958.83 \pm 101.35$ for sausage. Monosodium glutamate detected in all examined samples. Moreover, table (4) showed that 30 samples $(100 \%)$ of minced meat, 12 samples (40\%) of kofta, 6 samples $(20 \%)$ of beef burger and 6 samples $(20 \%)$ of sausage contain monosodium glutamate and not prescribed on the label of these samples and this disagree with the recommendation of EOS (2010).

Table (1): Statistical analysis of nitrite contents (ppm) in the examined samples of meat products

\begin{tabular}{|c|c|c|c|c|c|c|c|}
\hline \multirow[t]{2}{*}{ Meat products } & \multicolumn{2}{|c|}{ +ve samples } & \multicolumn{2}{|c|}{$\begin{array}{c}\text { Not prescribed on } \\
\text { label }\end{array}$} & \multirow[t]{2}{*}{ Min } & \multirow[t]{2}{*}{ Max } & \multirow[t]{2}{*}{ Mean \pm S.E } \\
\hline & No & $\%$ & No & $\%$ & & & \\
\hline Minced meat & 14 & 46.7 & 14 & 46.7 & 15.98 & 40.98 & $24.14 \pm 1.96^{\mathrm{c}}$ \\
\hline Kofta & 30 & 100 & 18 & 60 & 16.24 & 81.34 & $38.53 \pm 2.17^{\mathrm{ab}}$ \\
\hline Beef burger & 26 & 86.7 & 25 & 83.33 & 20.56 & 68.65 & $36.89 \pm 2.02^{b}$ \\
\hline Sausage & 30 & 100 & 13 & 43.33 & 7.02 & 83.01 & $43.59 \pm 2.33^{a}$ \\
\hline
\end{tabular}

Table (2): Statistical analysis of phosphate contents (\%) in the examined samples of meat products $(n=30)$.

\begin{tabular}{|c|c|c|c|c|c|c|c|}
\hline \multirow[t]{2}{*}{ Meat products } & \multicolumn{2}{|c|}{ +ve samples } & \multicolumn{2}{|c|}{$\begin{array}{c}\text { Not prescribed } \\
\text { on label }\end{array}$} & Min & Max & Mean \pm S.E \\
\hline & No & $\%$ & No & $\%$ & & & \\
\hline Minced meat & 0 & 0 & 0 & 0 & - & - & - \\
\hline Kofta & 30 & 100 & 0 & 0 & 0.05 & 0.30 & $0.13 \pm 0.01^{\mathrm{a}}$ \\
\hline Beef burger & 12 & 40 & 0 & 0 & 0.11 & 0.28 & $0.21 \pm 0.01^{a}$ \\
\hline Sausage & 30 & 100 & 0 & 0 & 0.05 & 0.35 & $0.16 \pm 0.01^{\mathrm{a}}$ \\
\hline
\end{tabular}


Table (3): Statistical analysis of ascorbic acid contents (ppm) in the examined samples of meat products $(n=30)$.

\begin{tabular}{|c|c|c|c|c|c|c|c|}
\hline \multirow{3}{*}{ Meat products } & \multirow{2}{*}{\multicolumn{2}{|c|}{ +ve samples }} & \multirow{2}{*}{\multicolumn{2}{|c|}{$\begin{array}{c}\text { Not } \\
\text { prescribed on } \\
\text { label }\end{array}$}} & \multirow{3}{*}{ Min } & \multirow{3}{*}{ Max } & \multirow{3}{*}{ Mean \pm S.E } \\
\hline & & & & & & & \\
\hline & No & $\%$ & No & $\%$ & & & \\
\hline Minced meat & 6 & 20 & 0 & 0 & 106.6 & 115.7 & $111.33 \pm 9.49^{d}$ \\
\hline Kofta & 6 & 20 & 0 & 0 & 180.6 & 203.0 & $190.10 \pm 14.26^{c}$ \\
\hline Beef burger & 6 & 20 & 0 & 0 & 213.7 & 250.4 & $227.60 \pm 16.81^{b}$ \\
\hline Sausage & 26 & 86.7 & 0 & 0 & 261.0 & 270.0 & $265.67 \pm 21.04^{\mathrm{a}}$ \\
\hline
\end{tabular}

Table (4): Statistical analysis of monosodium glutamate contents $(\mathrm{mg} \%)$ in the examined samples of meat products $(n=30)$.

\begin{tabular}{lccccc}
\hline \multicolumn{1}{l}{ Meat products } & \multicolumn{2}{c}{ Not prescribed on } & & \\
& \multicolumn{2}{c}{ label } & Min & Max & Mean \pm S.E \\
Minced meat & 30 & 100 & 588.1 & 1284.7 & $983.12 \pm 45.71^{\mathrm{c}}$ \\
Kofta & 12 & 40 & 1119.8 & 3026.2 & $1849.27 \pm 92.69^{\mathrm{a}}$ \\
Beef burger & 6 & 20 & 752.3 & 1618.5 & $1139.90 \pm 73.14^{\mathrm{b}}$ \\
Sausage & 6 & 20 & 935.2 & 2675.1 & $1958.83 \pm 101.35^{\mathrm{a}}$ \\
\end{tabular}

\section{DISCUSSION}

The obtained nitrite level (ppm) results were nearly lower than that reported by Mohammed (1997) (30.2 ppm) for minced meat, Mohammed (1997) (62.9 ppm), Hamed (2001) (75.13 ppm)Nayel (2013) (79.56 \pm 6.25) and Amnah (2013) 50.60 \pm 5.37 for the examined beef kofta samples, Tolba et al. (1994) (112.8 \pm 10.5 ppm), EL-Zahaby (2013) (17.68 ppm),Nayel (2013) (94.04 5.20) and Amnah (2013) $(91.63 \pm 9.26 \mathrm{ppm})$ for the examined beef burger and Mohammed (1997) (117.6 ppm),Hamed (2001) (94.06 ppm), Nayel (2013) (127.15 \pm 6.24), Amnah (2013) (85.99 \pm 7.87$)$ and EL-Zahaby (2013) 125.25 for the examined sausage samples.
Regarding to the percentage of samples contain nitrite and not prescribed on the label, lower results were reported by Nayel (2013) 2 samples (10\%) for beef burger and one sample $(5 \%)$ of kofta.

According to EOS (2005), it was evident that $100 \%$ of the examined minced meat, kofta, beef burger and sausage were accepted (table 13). While 2 beef kofta samples $(6.66 \%)$ and 2 sausage samples $(6.66 \%)$ were unaccepted according to (Codex, 192/1995) (revised 2017) which mentioned that nitrite in meat and meat products must be not more than $(80 \mathrm{ppm})$.

Nitrite undergoes many different reactions and the residual content of nitrite in 
cured meat products is generally only a small fraction of the amount added because the nitrite reacts with components of the meat during processing and storage (Hammes, 2012).

Adding of nitrite to cured meat develops flavor and colour and retards the development of rancidity and off-odours and off-flavours during storage of cured meats. Nitrite prevents the growth of a harmful bacterium called Clostridium botulinum and it may also have preservation effects on other harmful and spoilage bacteria (Manassaram et al., 2006).

According to the obtained phosphate results for the examined samples, higher results were reported by Nayel (2013) $(0.38 \pm 0.029 \%)$ and Salim and El-Roos (2013) $(0.41 \pm 0.025)$ for beef kofta, EL-Sayed (2006), EL-Zahaby (2013) (0.399\%) Nayel (2013) $(0.43 \pm 0.02 \%)$ and Salim and El-Roos (2013) $(0.4 \pm 0.019 \%)$ for beef burger, also, higher results were recorded by Salim and ElRoos (2013) (0.53 $\pm 0.020 \%)$ EL-Zahaby

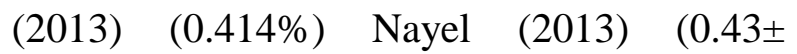
$0.019 \%$ ) for the examined sausage samples.

Regarding to the percentage of samples contained phosphate and not prescribed on the label, similar results were reported by Nayel (2013).

All of the examined beef kofta, beef burger and sausage were accepted according to EOS (2005). While 2 kofta samples (6.66\%), 2 beef burger samples $(6.66 \%)$ and 6 sausage samples (20\%) were unaccepted according to (Codex, 192/1995) (revised 2017) which mentioned that phosphate in meat and meat products must be not more than $(0.22 \%)$.

In the processing of meat and meat products phosphates are essential for several reasons such as, increasing $\mathrm{pH}$, increasing water holding capacity (WHC; structure of muscle protein is opened) in order to lead to higher yields and stabilized meat emulsions, decreasing cooking losses of weight, improving texture and sensory properties (tenderness, juiciness, color, flavor). In addition to extending shelf life (Lampila and Godber, 2002).

The phosphates offer a means of reducing sodium chloride concentrations without major losses in the water binding ability of the meat matrix. Phosphates have been shown to be significant contributors to antioxidant activity and flavor protection in processed meats, particularly in uncured products where nitrite is not included (Vasavada et al., 2006).

Regarding to the recorded ascorbic acid results for the examined samples, higher results were reported by Nayel (2013) $487.82 \pm 22.84$ for beef burger, 417.67 \pm 20.08 for sausage and $461.29 \pm 15.78$ for kofta.

Concerning to the percentage of samples contained ascorbic acid and not prescribed on the label, these results agree with (Nayel, 2013) for the results of beef burger and sausage, but disagree for the results of kofta 4 samples (20\%) not prescribed on label.

All of the examined minced meat, beef kofta, beef burger and sausage were accepted according to EOS (2005).Ascorbic acid in meat and meat products must be manufactured according to good manufacturing practice (GMP) (Codex, 192/1995) (revised 2017).

The current routine use of ascorbates (ascorbic acid, sodium ascorbate, erythorbic acid and sodium erythorbate) by the meat processing industry is important not only because it accelerates and improves the curing process but also the use of ascorbates inhibits nitrosation reactions which might result in formation of carcinogenic nitrosamines (Mirvish et al., 1995). Moreover, ascorbic acid resulted in much faster and more efficient reduction of the residual level of 
nitrite than several other antioxidants ( $\mathrm{Li}$ et al., 2013).

Regarding to the incidence of monosodium glutamate in the examined samples lower results were reported by Nayel (2013) (50\%) for beef burger, (10\%) for sausage and $(5 \%)$ for kofta.

Concerning to the percentage of samples contain monosodium glutamate and not prescribed on the label, lower results were reported by Nayel (2013) 2 samples (10\%) for sausage and one sample (5\%) of kofta, while beef burger 7 samples (35\%) were higher than the obtained results.

All of the examined minced meat, beef kofta, beef burger and sausage for monosodium glutamate were accepted according to EOS (2005). While Codex (192/1995) (revised 2017) mentioned that monosodium glutamate in meat and meat products must be manufactured according to good manufacturing practice (GMP).

When monosodium glutamate is added to foods in small quantities, the palatability of those foods is increased (Chi, 1998). Therefore, it is used to enhance flavor and are recognized as the "umami" (pronounced: oo-marmi) taste in the oriental cuisine. Many researchers believe that umami is a fifth taste, independent of the four basic tastes. MSG contributes a delicious umami taste to foods when used at levels in excess of their independent detection threshold, and they enhance flavors at levels below that (Barbut, 2002).Monosodium glutamate used in low fat foods to make up the flavor that lost when fat is reduced or eliminated (Gadekar, 2009).

Finally from the present study it was observed that there is a difference in chemical composition, amount and types of some preservatives detected in the same meat products with the same company, same preservatives and amount on the label. This indicated inadequate quality control and improper manufacture practice.

\section{RECOMMENDATION:}

Nitrosamine inhibiting agents as ascorbate, alpha tocopherol or both during the processing of meat products should be added to reduce the hazardous effects. Due to the potential for increased toxic effects of the chemicals used, and for the overall push for more natural products in the food industry, the food industry should look for more natural alternative for safe processing and storage of meat. Some berries, leaves, bulbs, roots and stems are known to contain substances that inhibit bacterial growth. In some plants the concentrations of these compounds is so high that they could perhaps be used to preserve foods. This theory should be tested in organic and conventional meat products.

\section{REFERENCES}

Amnah, M. A .Alsuhaibani (2013): Chemical and biological study on the effect of yoghurt on most common consumed ready meat products. Nutrition and Food Sciences Dept, Home Economic Collage, Princess Nora, Bint Abdul Rahman -University, Riyadh, Saudi ArabiaJournal of Applied Sciences Research, 9(3): 1426-1433.

Association of Official Analytical Chemists "AOAC" (2016): Official Methods of Analysis. 31 ${ }^{\text {th }}$ Ed., W. Horwitz (Editor), Academic Press, Washington, D. C., USA.

Barbut, S. (2002): Poultry Products Processing-An Industry Guide. CRC Press, Boca Raton. 259.

Chi, S. Y. (1998): Basic properties of umami and its effects on food flame. Food Reviews International, 14, 139-176.

Davidson, P. M. (2001): Chemical preservatives and natural antimicrobial compounds, In food microbiology: Fundamentals and fronties. Doyle, M. P., Beuuchat, L. 
R., Montville, T. J. editors. Washington, DC: ASM press.

Denner, W. H. B. (1990): Food additives, recommendations for harmonization and control. Review, Food Control, J., 42: 150- 162.

Egyptian Organization for Standardization and Quality control "EOS" (2005): Detection of food preservatives. Report No. 1688, 1694, 1972 and 1973.

EL-Sayed, A. E. (2006): Organolytic and chemical evaluation of some locally manufactured beef burger. M.V.Sc. Thesis, (Meat Hygiene). Fac. Vet. Med., Benha Univ.

EL-Shazeli, M.G., EL-Zalaki, E.M. Mohamed, M.S. and Aman, M.B. (1980a): Technological, chemical and microbiological studies on semidry sausage. Alex. J. Agric. Res., 28 (1): 107-112.

EL-Zahaby, D. I. (2013): Chemical evaluation of some food additives in meat products. Ph. D.V.Sc. Thesis, (Meat Hygiene). Fac. Vet. Med., Benha Univ.

Faustman C. and Cassens RG. 1989: Strategies for improving fresh meat color. Proceedings of the 35th ICoMST Proceedings; 20-25 August; Copenhagen, Denmark. Roskilde: Danish Meat Research Institute. 44653.

Gadekar, Y. P., A. S. R. Anjaneyulu, R. Banerjee, R. Suresh, R. D. Kokane, A. K. Das \& B. D. Sharma (2009): Nonmeat Ingredients in Meat Processing. Beverage and Food World 36(1):34-38.

Hamed- Manal, I. A. (2001): Chemical evaluation of non- meat ingredients in some meat products. M.V. Sc. Thesis. Fac. Vet. Med., Cairo Univ.

Hammes, W. P. (2012): Metabolism of nitrate in fermented meats: the characteristic feature of a specific group of fermented foods. Food microbiology, 29(2), 151-156.

Ho, C. P., McMillin, K. W. and Huang, N. Y. (1996): Ground beef lipid, color and microsomal stability in gas exchange modified atmosphere packaging. Proc IFT Ann Meet, New Orleans, LA, 162.

Jinap, S. and Hajeb, P. (2010): Glutamate. Its applications in food and contribution to health. Appetite, 55(1), 1-10.

Jouve, J. L., Carlier, V. and Rozier, J. (1980): Antimicrobial effects of nitrates in meat products. In Annales de la nutrition et de l'alimentation (Vol. 34, No. 5-6, pp. 807-826).

Lampila, L.E and Godber, J.P (2002): Food Phosphates. In A. L. Branen, P.M. Davidson, S. Salminen and J. H. Thorngate III (Eds.), Food Additives 2nd edition (Chapter 25). Marcel Dekker, Inc., New York.

Lateef, M.; Siddique, K.; Saleem, M. and Iqbal, L. (2012): Estimation of Monosodium Glutamate by Modified HPLC Method in Various Pakistani Spices Formula.J. Chem. Soc. Pak. 34(1): 39-42.

Li, L., Shao, J., Zhu, X., Zhou, G. and Xu, X. (2013): Effect of plant polyphenols and ascorbic acid on lipid oxidation, residual nitrite and $\mathrm{N}$-nitrosamines formation in dry-cured sausage. International Journal of Food Science \& Technology, 48(6), 11571164

Libby, J.A. (1975): Meat Hygiene. $4^{\text {th }}$ Ed., Lea and Febiger, philadelphia, USA.

Long, N. H. B. S., Gál, R. and Buňka, F. (2011): Use of phosphates in meat products. African Journal of Biotechnology, 10(86), 19874-19882.

Lotfi, A. Y. and Youssef, K. E. (1966): comparative study concerning chemical and bacteriological 
evaluation of locally manufactured imported dry and semi dry sausage. Egypt Vet. Med. J., 13:35-39.

Manassaram, D.M.; Backer L.C. and Moll D.M. (2006): A review of nitrates in drinking water: Maternal exposure and adverse reproductive and developmental outcomes. Environmental Health Perspective, 114 (3): 320-327.

Mirvish, S. S., Grandjean, A. C., Reimers, K. J., Connelly, B. J., Chen, S. C., Gallagher, J., Rosinsky S., Nie G., Tuatoo H., Payne S., Hinman C. and Ruby. E.I (1995): Dosing time with ascorbic acid and nitrate, gum and tobacco chewing, fasting, and other factors affecting $\mathrm{N}$-nitrosoproline formation in healthy subjects taking proline with a standard meal. Cancer Epidemiology and Prevention Biomarkers, 4(7), 775-782.

Mohammed, M. M. S. (1997). Quality studies on market frozen meat products. M. V. Sc.Department of Food Hygeine and Control. Fac. Vet. Med., Cairo Univ.

Mohammed, M. M. S. (2002): quality improvement of some Egyptian frozen meat products. Ph.D. Department of Food Hygeine and Control. Fac. Vet. Med., Cairo Univ.

Nayel, M. S. (2013): Studies on chemical preservatives in meat products. $\mathrm{Ph}$. D.V.Sc. Thesis, (Meat Hygiene). Fac. Vet. Med., Benha Univ.

Pearson, A. M. and Gillett, T. A. (1996): Processed Meats. (3rd edn.), Pp: 54-55, 61-62, and 328-331.

Pivnick, H., Johnston, M. A., Thacker, C. and Loynes, R. (1970): Effect of nitrite on destruction and germination of Clostridium botulinum and putrefactive anaerobes 3679 and $3679 \mathrm{~h}$ in meat and in buffer. Canadian Institute of Food Technology Journal, 3(3), 103-109.

Salim, D. A. and El-Roos, N. A. A. (2013): Detection of phosphates and hydroxyprpline in some meat products. BVMJ-25 (1): 1-9.

Tolba, K. S., Abdel Aziz A. S. and Niazi, Z. (1994): Chemical analysis of locally manufactured meat product. Vet. Med. J., 42(3): 79-84.

Vasavada, M. N., Dwivedi, S., \& Cornforth, D. (2006). Evaluation of garam masala spices and phosphates as antioxidants in cooked ground beef. Journal of Food Science, 71(5). 